\title{
The long-term adaptation of a resource periphery as narrated by local policy-makers in Lieksa
}

\author{
MAIJA HALONEN
}

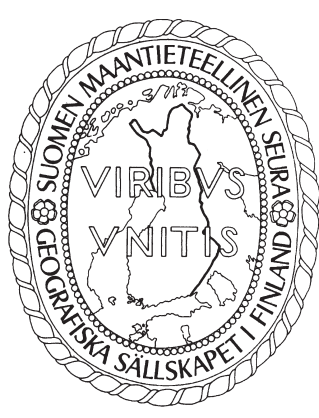

Halonen, M. (2019) The long-term adaptation of a resource periphery as narrated by local policy-makers in Lieksa. Fennia 197(1) 40-57. https://doi.org/10.11143/fennia.74368

$\mathbf{y}$ The paper's general objective is to question the point of view whereby peripheries are seen only through a static downturn with no reflections on dynamicity or adaptation. The focus is set on the standpoints of actors in local government and their interface with the broader structures. The aim is to create a productive dialogue with evolutionary economic geography studies paying attention to actors and resilience studies where the human perspectives in adaptation are emphasised. The town of Lieksa, Finland, is used as a case study to exemplify a forest resource periphery located in relative isolation at the regional and national scale, but within a developed economy in Europe. The results, based on interviews with key local policy-makers, show that development did not stop at the time of the first bust despite the domination of the downturn. The study reveals two waves of restructuring which both include a type of regional bust followed by different kinds of institutional recovery. In general, the human adaptation appears as reactions reflecting the variation of giving up, forward-looking acceptance, desperate resistance, re-orientation with external support and search for renewal with an optimistic attitude. Above all, the resilience regarding the local governmental actors emphasises their flexible adaptability and ability to develop institutional capacities to tolerate their vulnerability, the uncertainties of the economic future and the difficulties of locals to influence it - and if anything - to act and bounce forward in spite of repetitive busts and restructuring phases.

Keywords: evolutionary economic geography, regional resilience, resource periphery, peripheralisation, local decision-making, narrative analysis

Maija Halonen, Karelian Institute, University of Eastern Finland, P.O. Box 111, 80101 Joensuu, Finland. E-mail: maija.halonen@uef.fi

\section{Introduction}

The transformation of northern resource-based peripheries has been contextualised by continuous economic restructuring in advanced economies since the mid-1900s. The boom and bust of the resource cycle are central to understanding the background of this restructuring (Clapp 1998; Markey \& Heisler 2010; Ryser et al. 2014). As per a traditional model, only three phases can be observed: the initial boom, large-scale exploitation and ultimate collapse (Clapp 1998; Hayter 2000, 19; Ryser et al. 2014). Collapse has led to restructuring which is often characterised by shrinking socio-economic structures, declining employment, depopulation and high proportions of ageing people (e.g. Bryant \& Joseph 2001; Polèse \& 
Shearmur 2006; Lehtonen \& Tykkyläinen 2014). By the downward trends, increasing demographic isolation, power imbalances and the absence of realistic alternatives for diversified development, the vulnerability has become a characteristic of resource peripheries (Freudenburg 1992).

In the latest research, the development of the peripheries is still made up of booms and busts but attention is turning to regional waves, reflecting the multidimensional character of restructuring rather than focusing on the boom and bust of one sector (Jacquet \& Kay 2014; Ryser et al. 2014). The whole concept of the periphery as having a static predestined position has also been compromised, which has required the remapping of the changing role of the periphery (Kortelainen \& Rannikko 2015; Kühn 2015). Newer pathways have brought periphery studies closer to the dynamic orientation through the concepts of path dependency, industry life cycles and adaptation with the weight set on the institutions (Halseth et al. 2017; Ryser et al. 2018). These pathways have also given rise to the framework of regional resilience - often blending in part with evolutionary economic geography (EEG) in the context of peripheries (Carlsson et al. 2014; Isaksen 2015; Kotilainen et al. 2015; Vatanen \& Kotilainen 2016; Hayter \& Nieweler 2018).

The mainstream theories of economic geography have rarely been seamlessly adaptable to peripheries whose industrial, environmental, cultural and geopolitical development diverge from the cores (Hayter et al. 2003; Kortelainen \& Rannikko 2015). As a result, differentiated institutional perspectives and path-dependent development patterns have been found (Hayter et al. 2003; Isaksen 2015). In particular, the standpoints of local governments and their interface with the broader structures are seen as substantial when investigating the peripheries, but which tend to be overlooked in core-based studies with an emphasis on endogenous development and industrial processes and outcomes (Isaksen 2015; Hayter \& Nieweler 2018; Ryser et al. 2018).

This article attempts to create a productive dialogue with those EEG studies that have paid attention to actors - especially in local decision-making beyond the firm level - institutional changes within and outside of a region and unevenness of places (see Hodgson 2009; MacKinnon et al. 2009; Bathelt \& Glückler 2014; Hassink et al. 2014; Martin \& Sunley 2015a; Pike et al. 2016). The critical voices towards quantified macro-level approaches in resilience are taken seriously and the human perspectives in adaptation are emphasised by exploring the cognitive processes of local actors - their knowledge in the face of the unknown and reactions among changing structural environment (see Hudson 2009; Bristow \& Healy 2014; Gong \& Hassink 2017).

The paper's general objective is to question the point of view whereby peripheries are seen only through a static downturn with no reflections on dynamicity or adaptation. 'Periphery' is understood here as a concept that connects the case of Lieksa, Finland, to a context that sets boundaries for adaptation but, as such, does not prevent the evolution. The town of Lieksa with its 4,000 $\mathrm{km}^{2}$ hinterland represents a Finnish resource periphery in the industrialised North situated in the most land-locked part of Fennoscandia in the vicinity of the Russian border (Tykkyläinen et al. 2017). Local policy-makers are seen as a way to investigate not only the changes in formal institutions influencing adaptation but also to gain information about informal institutions that shape the mutable position of the locals. Through this framework, the paper examines: 1) What kinds of waves of restructuring and forms of adaptation can be found based on the interviews with local policy-makers?, 2) What kinds of formal and informal institutions have influenced adaptation and how have these institutions changed over time?, and 3) How have experiences from the previous wave affected adaptation during the last wave? These questions are investigated in the long-term, by starting from the tail end of the initial boom in the 1940s and by focusing on the waves of restructuring since the 1960s.

\section{Premises for the evolutionary adaptation of a resource periphery}

\section{Peripheries with resources, booms and busts}

'Periphery' refers here to the remote sparsely populated rural region situated in the border area at great distance to the centres (cf. Kühn 2015). These physical structures may appear persistent, but neither the structures of the economic landscape nor the regional economy within the periphery are 
static by their nature. For resource peripheries, the initial boom cycle results from the extraction of natural resources. The 'boom' describes the domino effect caused by increased demand for natural resources followed by exponential growth in extraction leading to a high demand for the workforce and construction of infrastructure, finally accelerating population growth and thus new demands for municipal services (Jacquet \& Kay 2014; Deacon \& Lamanes 2015; Keough 2015). Such booms can be found on the peripheries in developed countries where growth has developed intensively after the Second World War (WWII) within a relatively protected trading network and the state has made significant investments especially in developing the infrastructure (Halseth 2017).

The 'bust' representing the abrupt decline results from deep shocks such as collapse in demand, the overexploitation of the resource or changes in market access, transportation or production technologies, often leading to declining employment together with industry adjustment, downsizing or closures (Clapp 1998; Keough 2015; Kortelainen \& Rannikko 2015; Kotilainen et al. 2015; Halseth 2017). Restructuring resulting from bust is portrayed as a multi-causal, contingent and path dependent process with uncertainty about the future, thus being anything but straightforward, mechanical or easy from the perspective of local policy-makers planning for long-term timelines (Markey \& Heisler 2010; Hayter \& Nieweler 2018).

For the resource peripheries, the closures, openings and redirections of economic connections that radically change the positionality of local economies are essential parts of the transformation processes (Kortelainen \& Rannikko 2015). While different kinds of market forces induce economic development, the interactions of various actors at different spatial scales are seen to play a role in the geographically variable development of places (Martin 2000). 'Peripheralisation' refers to such a process where the role of the periphery is mostly externally reproduced through the economic, social, political and communicative interaction between actors (Kühn 2015).

The changes may appear as disruptions in protected and supported trading networks resulting from globalisation or as diminished state investments caused by the adoption of neoliberal policy approaches (Halseth 2017; Halseth \& Ryser 2017, 98-105). Although the locals are seen as having little control over the development that is significantly driven by external conditions, currently the wider policies and the support of central government are compensated by the greater responsibility of local actors in the creation of economic development (Keough 2015; Halseth 2017; Hayter \& Nieweler 2018). This has led the local governmental actors into a confusing process of transformation where the role is redefined and repositioned, but the structures including the legal and practical tools are outdated leading to poorly resourced possibilities to respond to the changing role (Halseth \& Ryser 2017, 162-163). This dramatically re-shaped relationship between the state and the periphery (Markey \& Heisler 2010) that relates to globalisation and moving towards neoliberal policies is understood here as a significant part of the institutional changes reproducing peripheralisation and influencing the adaptation of the periphery.

\section{Institutions in evolution}

Peripheries are understood here as evolving economic and societal systems which are influenced by actors at various spatial scales (cf. Martin \& Sunley 2006; Pike et al. 2016). In order to attain a greater understanding of the variable development of regions and localities, the role of institutions, actors and spatial policies must be investigated (Hassink et al. 2014; Martin \& Sunley 2015a). Attention is directed to the question of how spatial policy and socio-economic structures emerge from institutions and the behaviours of actors (Boschma \& Martin 2007), and how actors' beliefs shape understandings of socio-economic evolution (Hodgson 2009).

Path dependence is understood here as behaviour that reproduces these institutional forms (Hudson 2005), which essentially means that a path-dependent process or system evolves from the basis of its own history, meaning that the future is dependent on the steps taken in the past (Martin \& Sunley 2006). Path dependence is not understood as good or bad, but rather as limiting the available choices for the next step and setting the terms of development (Martin \& Sunley 2006; Henning et al. 2013).

This article adopts the perspective of institutions as informal conventions, norms and social routines, as well as the formal rules and regulations that steer the socio-economic environment and 
human behaviour generating patterns of interaction between the actors (Martin 2000; Bathelt \& Glückler 2014). Institutions are understood as mediators of the interactions that uphold spatial variety, resulting in different economic landscapes with different historical path dependencies and unevenly developed economies (Mackinnon et al. 2009). This interplay is upheld by actors across scales, although institutions tend to be geographically and temporally embedded in places (Essletzbichler \& Rigby 2007; Hassink et al. 2014).

Some actors are expected to be structurally more powerful than others, influencing uneven sociospatial relations (Pike et al. 2009). Although the evolutionary approach rejects, in principle, ideas of destiny and inevitable process (Hodgson 2009) as well as predetermined and fixed power hierarchies (Hassink et al. 2014), places tend to be tied to certain hierarchical roles by past decisions (MacKinnon et al. 2009). In this context, the outcome reflects the marginalisation and powerlessness of peripheries, a role that is upheld by institutions and economic decline. This does not suggest that the role is persistent; rather, it is evolving together with the changing institutions (Bathelt \& Glückler 2014). Given that institutions can provide stability and buffers during crises, they have a tendency to be thick and sticky, which often leads to the slowing down of both changes and adaptation (Essletzbichler \& Rigby 2007).

\section{Resilience in adaptation}

Peripheries operating in a politically marginalised and vulnerable position are considered to suffer from the consequences of external shocks, which can comprise sudden events or long-lasting transformation processes (Adger 2006; Kühn 2015; Tykkyläinen 2015). The question arises of how they maintain long-term development and adapt to short-term shocks and long-term stresses (cf. Simmie \& Martin 2010; Boschma 2015). Here, the adaptation is seen as an ongoing process that concerns the restless development of a region where evolutionary resilience is observed as the reactions and reconfigurations of structures following a disturbance (Dawley et al. 2010; Boschma 2015; Martin \& Sunley 2015b). In this context, peripheries face pressure to transform and renew their economic and institutional structures in order to recover and adapt to the challenging socio-economic conditions (Simmie \& Martin 2010; Markey et al. 2012).

In some cases, the resilience approach has been interpreted as overemphasising the need for flexibility, self-help and competitive fitness from the locals by neglecting the impact of external factors such as the role of the state, institutions and policies (see Hassink 2010). This seems also to be a flaw in practice as the central-level authorities have increased their expectations of local development but failed to provide the power, resources or authority to the locals in order to meet the new expectations (Ryser et al. 2018). The paradox is that the resource peripheries especially, are seen as having defects in endogenous resources and limited capacity to adapt to change for which reasons it requires supplemental support and direction from the state or central government (Markey \& Heisler 2010; Carlsson et al. 2014). As Hayter and Nieweler $(2018,86)$ express it, there is "the need to somehow brainstorm initiatives and generate institutional capacity, often simply to maintain the status quo or slow the rate of decline". Given that the state government is seen as a centrally important actor by controlling local governance and resources available to local actors (Pike et al. 2010), an examination of resilience should include paying attention to how national policy assists or hinders local recovery and how local institutional and political conditions respond to these policies (cf. Martin 2012).

Similarly than the whole process of restructuring, the process of adaptation can be portrayed as anything but straightforward or mechanical. It demands weaving inside the nested adaptive cycles interacting between the scales and including pressures from both acute shocks and slow-burn stresses (Pendall et al. 2010). It can also require navigating between regional waves which may represent the simultaneous responses to both the booms and busts of various sectors (Ryser et al. 2014). Along these waves, the process of adaptation may take different forms, varying from resistance and recovery to re-orientation and renewal resulting in different outcomes (cf. Martin 2012). Interests may also diverge and come into conflict (MacKinnon et al. 2009) which creates political debate between actors (Martin 2012). However, when creating local resilience, some similarity of interests among actors and overlapping institutional structures is needed that bears out the supportive basis for the change and actors with the ability to lead (cf. Boschma 2015). 
When scrutinising resilience from the perspective of actors on the periphery, attention continues to be directed towards adaptability by developing capacities to reduce vulnerability but also increase the ability to tolerate and confront the uncertainties and economic inefficiencies (Hudson 2009; Dawley et al. 2010). Thus, it is important to pay attention to how local actors interpret and articulate changes in economic conditions and how these interpretations shape local actors' reactions to the changes (Bristow \& Healy 2014). After all, as the policy-makers act based on their perceptions, expectations and conventions (Martin \& Sunley 2015b), the focus must be placed on the question of how the adaptation is lived, experienced and narrated along the path. This can be examined through analysing how local actors describe and explain the change, their vulnerability and strategies, and capacities to deal with change (cf. Brown 2016).

\section{Narrated case study as a method}

\section{Narratives comprised of interviews with local policy-makers}

The research method used here is an empirical case study through which temporal socio-economic adaptation is examined within its real-life policy-making context, and with prior conceptual information utilised for support (e.g. Yin 2003). The methodological orientation adopts the idea of following the evolutionary path of the locality by utilising interview data as a means of capturing the socio-spatial relations and processes that depict economic development and regional policies, as well as the behaviours of actors (Pike et al. 2016). The data accord with inductive field research, which includes the collection of historical narratives of local socio-economic change by affording interviewees a relatively large amount of freedom to describe structural changes, adaptation and their understandings of the position of their locality during the restructuring phases (cf. Martin \& Sunley 2015a).

The research adheres to narrative orientation by moving from the use of numbers to words, and changing the focus from the general and universal towards the local and specific (Pinnegar \& Daynes 2007). By using narrative inquiry, focus is placed on the interaction between society and actors, temporal continuity (past, present and future), and the specific place where the phenomenon occurs (Clandinin \& Connelly 2000). Given that the objective is to analyse adaptation where it actually occurs (cf. Martin 2012), the narratives are produced from the position of the actors of local decision-making bodies representing the perspectives of local government. As is true of any narrative produced during an interview, the narrative of each storyteller is an assemblage of smaller episodic stories, which collectively offer a description of the series of events and decisions concerning economic development (Pinnegar \& Daynes 2007; Estola et al. 2017). As much as the narratives reveal the experiences of individuals, they should be seen as a combination of first-hand and historic narratives. Each narrative represents the standpoint of wider social constructions from the past in the cognitive context of the interview (Clandinin \& Connelly 2000; Andrews 2015; Hyvärinen 2017).

The interviews were conducted during the period of economic stagnation in 2010 and 2011, in the aftermath of the Great Recession of 2008-2010. In practice, all available key policy-makers of the town authority in Lieksa were interviewed. These eight policy-makers were either holders of an office or political actors and they were selected on the basis of the knowledge they had gained during their long experience in public decision-making (Table 1).

Two retired policy-makers were chosen due to their long experience and wide-ranging perceptions of the town's policy processes. As all interviewees but one had acted in policy-making for several years or even decades, they were able to complement the historical information on the basis of their firsthand experiences and memories. The narratives were analysed using content analysis as a method that enables the making of replicable inferences from texts (Krippendorff 2004). The interviews were organised under themes that reflect episodic changes and means of adaptation using phrases, sentences or paragraphs as units for analysis. These were re-contextualised on the basis of previous literature (cf. Krippendorff 2004) referring to conceptual information pertaining to EEG and resilience studies, and contextual information regarding the resource peripheries and the case study area. The analysis is supported by excerpts from the interviews, translated from Finnish to English by the author. 
Table 1. The latest position(s) of interviewees and years in local public duties in total.

\begin{tabular}{l|c}
\hline Latest position at the time of interviews & Years in total \\
\hline town manager & $20<$ \\
city treasurer (retired) + chairman of board of the industrial estate & $30<$ \\
rural manager (retired) & $30<$ \\
rural manager & $10<$ \\
technical manager & $10<$ \\
member of the Finnish Parliament (current) + chairman of the municipal council (current) + incumbent (retired) & $20<$ \\
chairman of municipal board (current) + incumbent (retired) & $30<$ \\
chairman of municipal board & $10>$ \\
\hline
\end{tabular}

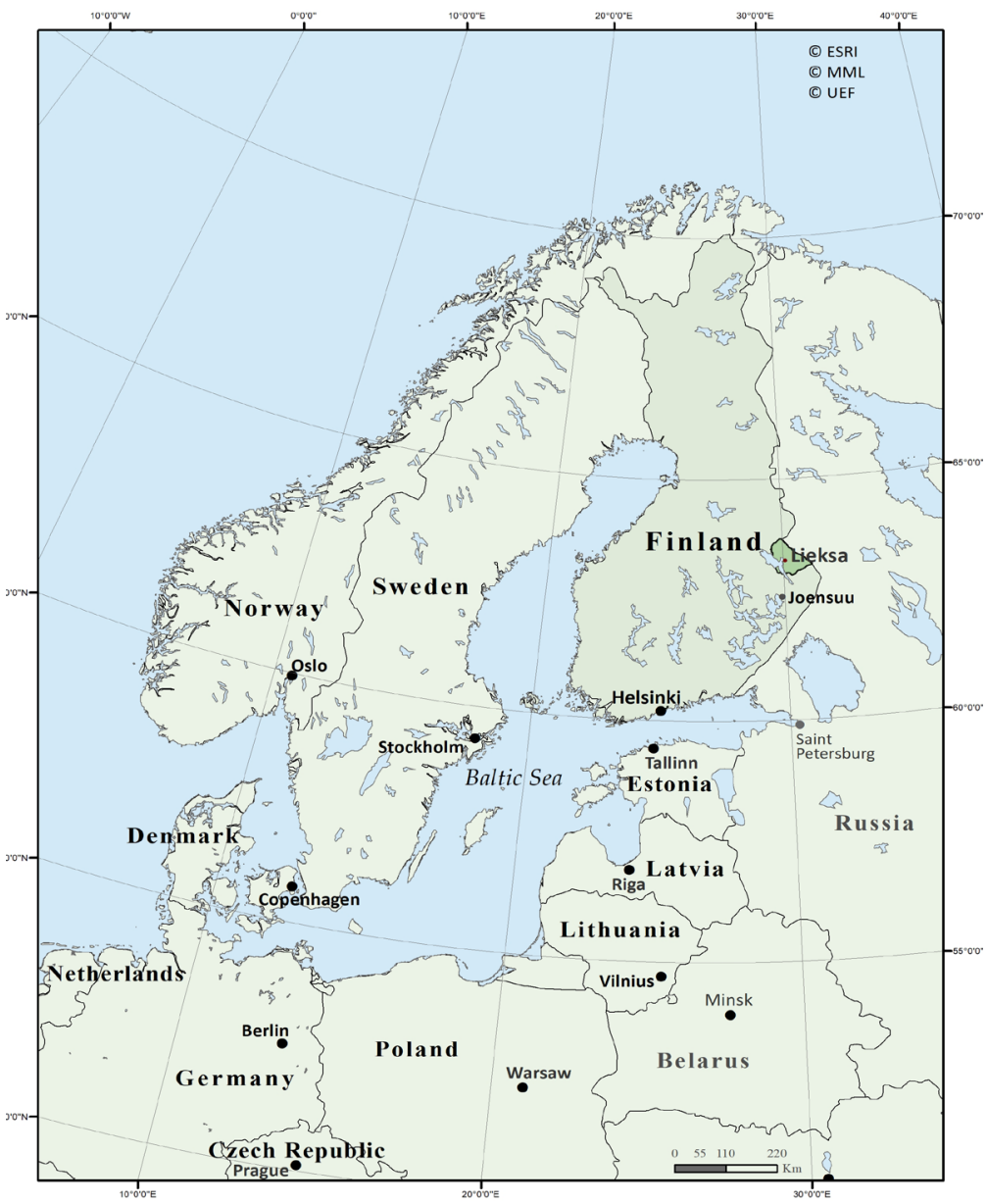

Fig. 1. Lieksa as a distant periphery from the regional centre Joensuu (ca. 100 km) and capital city Helsinki (ca. 500 km).
The excerpts appear in the same form as the transcribed interview data. The interviewees are anonymised using codes from 11 to 18.

\section{Case study of Lieksa as a resource periphery}

The case study town of Lieksa was chosen as it represents a typical periphery with a relatively small population, weak urban system and considerable distance from major markets (Polèse \& Shearmur 2006). It is a sparsely populated forest resource periphery situated close to the Russian border and in a relatively isolated location at the regional and national scale, but within a developed economy in Europe (cf. Halseth 2017; Fig. 1.). As a whole, the Lieksa municipality covers 4,000 $\mathrm{km}^{2}$, with about $80 \%$ of its 11,500 inhabitants living in its centre $\left(63^{\circ} 19^{\prime} \mathrm{N}, 30^{\circ} 01^{\prime} \mathrm{E}\right)$. This centre is nationally classified as a local centre in rural areas with a relatively intense structure having over 400 inhabitants per square kilometre and jobs numbering more than 2,000. Its commuter belt concentrates on primary production in agriculture after which scattered sparsely populated areas begin with extensive forest and wetlands (see Helminen et al. 2014). 
In Lieksa, the initial boom of the forest-industry dates from the beginning of the $20^{\text {th }}$ century (Tykkyläinen et al. 2017) when the growing European timber market expanded the utilisation of forest resources, increasing the demand for the local labour force (Aarnio 1999, 166-173) and accelerating population growth (Halonen et al. 2015). Rural population growth was sustained up to the mid-1960s, with the assistance of the Finnish government, as a corollary of the post-WWII settlement policy when 9.1\% of the land area was redistributed through the Land Acquisition Act (Tykkyläinen 1995, 139-140). It consolidated Lieksa's position as a resource periphery of forestry and small-scale farming (Saarelainen 1995) and increased employment in public services offered for the growing population (Fig. 2).

A severe bust followed less than two decades later, in the 1960s, and initiated the first wave of restructuring (Fig. 2). Mechanised logging increased productivity in forest work but resulted in a deep decline in jobs in forestry work (Kotilainen et al. 2015) that was exacerbated by closures of unprofitable small-scale farming (Rannikko 1999). With the rationalisation of primary production, the entry of the baby boom generation to the labour market and the temptation of urban lifestyles, whole families left their homes and moved to bigger cities in Finland or even further to Sweden (cf. Rannikko 1999). From the late 1960s, the restructuring was mitigated through formal institutions, initially by regional policy

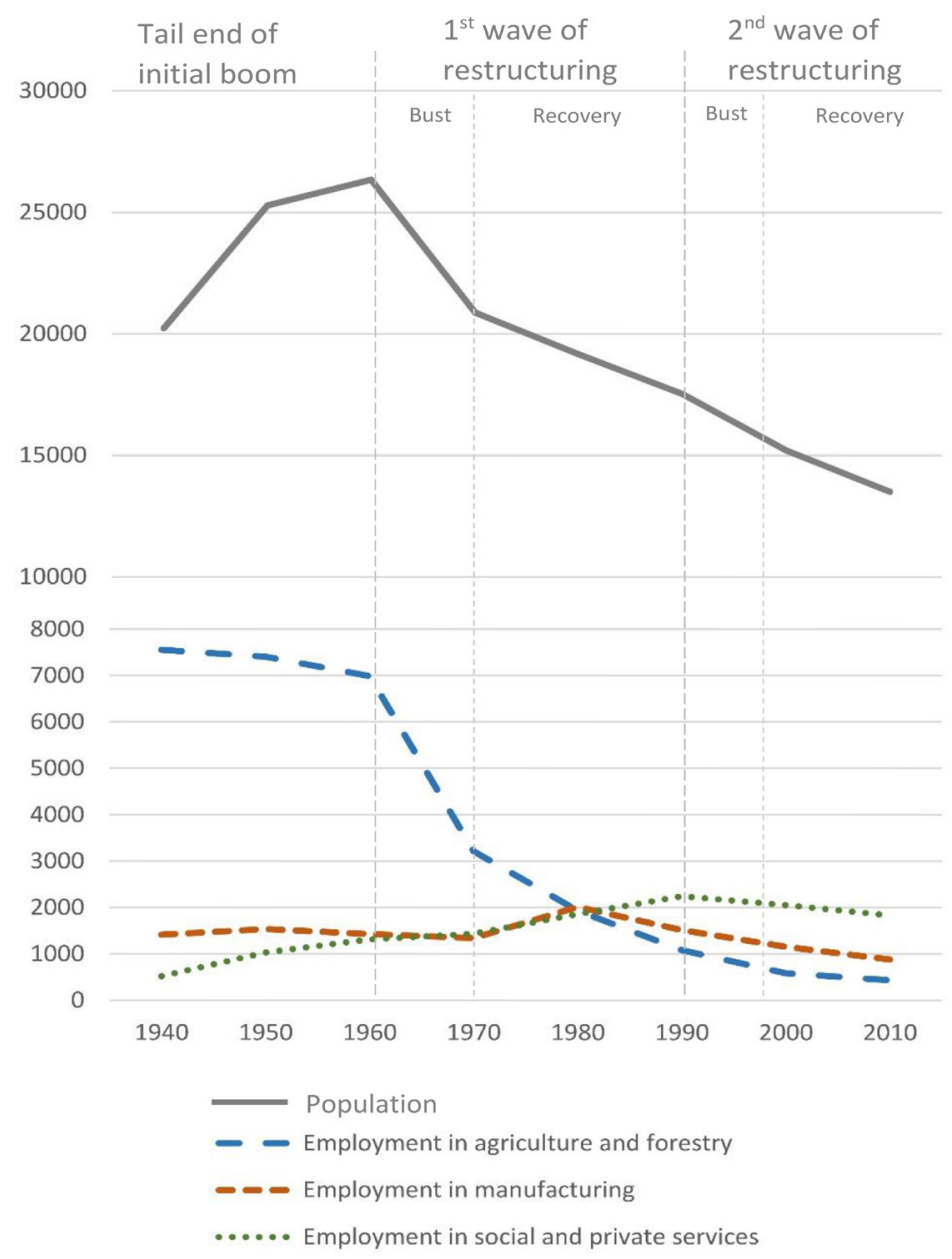

Fig. 2. The population and employment by main sectors $1940-$ 2010 (sources: Statistics Finland 1979, 2018a). 


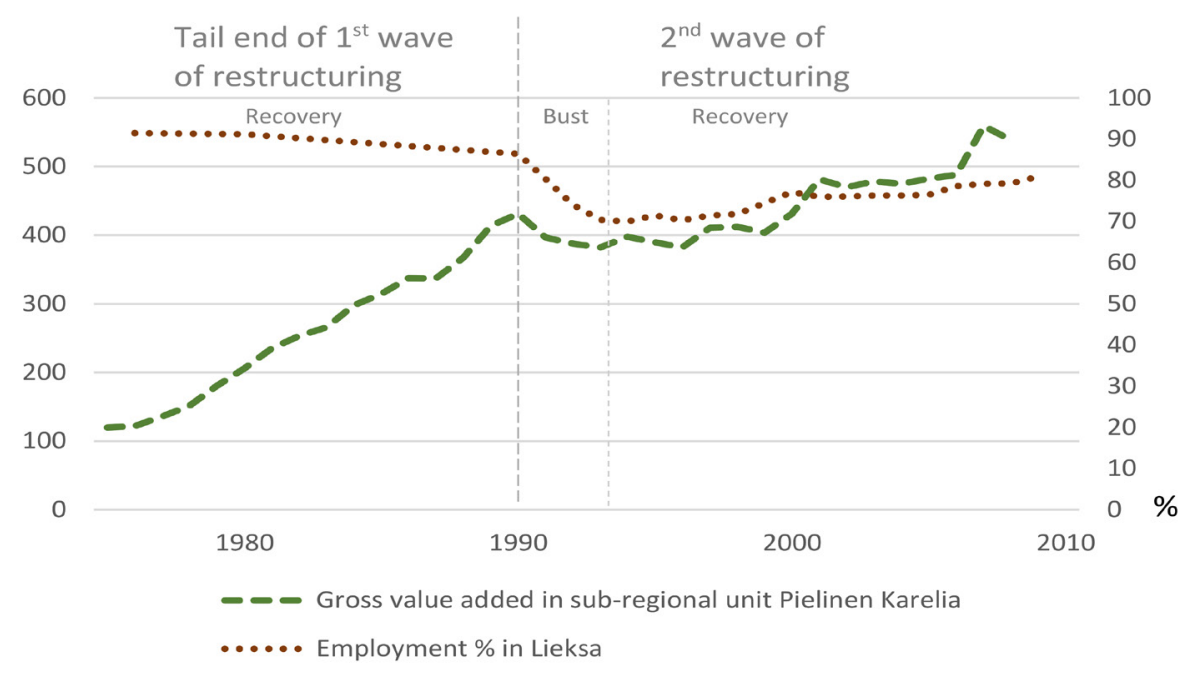

Fig. 3. Gross value added of output and employment ${ }^{1}$ in sub-regional unit Pielinen Karelia and employment \%, employed \% of the labour force ${ }^{2}$ in Lieksa (sources: Lieksa 1980; Statistics Finland 1982, 2010, 2018a).

funding that was allocated to disadvantaged regions (Moisio \& Leppänen 2007), which also advanced the establishment of the industrial estate in Lieksa. Foundations for increasing the export of manufactured goods were laid through institutional agreements that Finland made with the European Free Trade Association (EFTA) in 1961 and with Comecon countries in the 1970s (Kotilainen et al. 2017). In parallel, the establishment of spatially equal welfare services and decentralisation of public tasks represented formal institutions that alleviated the decline. Employment in manufacturing related to low-cost mass production and public services following the Nordic welfare state model resulted in growth, while primary production continued its downhill trend (Tykkyläinen et al. 2017; Fig. 2). In total, the employment of the labour force in Lieksa was stabilised adhering to a gradual decline rather than increased, but output and employment were seemingly value added in Pielinen Karelia (Fig. 3) - the sub-region of four municipalities, Lieksa being the biggest by population and workplaces (Statistics Finland 2018b).

The next bust took place in the 1990s and initiated the second wave of restructuring. Since then no growth has been observed in either population or employment in any of the main three sectors (Fig. 2). At the beginning of the second wave, the nationwide recession led to a plunge in demand in the domestic market and cuts to public spending (Kiander 2001, 36-39), while simultaneously exports to the Soviet market came to an end. This turbulent time can be seen as a slump in both the employment of the labour force and the value added of output and employment (Fig. 3). This was also a time of changes in the institutional atmosphere. The political aspirations and the accession of Finland to the European Union (EU) in 1995 diminished the support for the disadvantaged regions and tended to stress the growth policies and strengths of competitive regions (Kortelainen 2010, 353-356), thus decreasing the opportunities of Finnish peripheries (Suorsa 2007). These institutional changes replicate the common challenges of peripheries following the adoption of neoliberal policies.

\section{Empirical findings regarding institutional changes and adaptation}

\section{Tail end of the initial boom followed by the shock of the first bust}

The narratives explaining the tail end of the initial boom from the late 1940s reflect the history of a livelihood based on natural resources that enabled the purchasing of land for small-scale farming 
and the availability of forest work: "With small-scale farming and forestry work people survived" (12). The emphasis is set on the influence of the formal institutional policies on population growth after WWII, but these narratives can also be seen to reflect the informal construction of peripheralisation. By underlining the compensation for the clearing of land that has only a negligible role in the clearing of fields under the Land Acquisition Act (Maatalousministeriön asutusasiainosasto 1953; Central Statistical Office 1970), an interviewee added weight to the position of Lieksa as a distant periphery:

Many neighbourhoods were established after the war. ... A village was established as a result of so-called Swedish clearing ${ }^{3}$, that is Finland-Swedish land owners, who did not want to donate their land, paid in order to [compensate their obligation to dispose the land and get] the farms cleared elsewhere, in the periphery (I3).

This positioning not only as a distant but also as a border periphery was supplemented by a description of informal political reasoning that aimed at strengthening military security against the Soviet Union which in retrospect proved to be strategically outdated: "Settlement at the border was favoured, and the prevention of its depopulation. It was a military understanding back then, but nowadays no one anticipates that aggression towards Finland would occur as front lines through the border" (I1).

The interviewees had very little to say about the role of local decision-making in this process after the war, but rather they presented the town as a small cog in a larger national development machine. The adaptation is strongly considered as reactions representing the imbalanced power of local government within the national decision-making system. As typical on peripheries, the most tangible task of the local authority was to take part in the construction of the basic infrastructure and services for the growing population that turned out to be temporary if anything:

Back then, a school was established in almost every village; it was based on colonisation. Residential loss, which happened most severely at the turn of the seventies, depopulated these villages in a few years. It was said jokingly that the roads were built, then the electricity. Then came TV, where people saw how life is lived in the big world. So, they run away. Left for southern Finland and Sweden (I1).

The narratives describing the first bust in the 1960s reflect the depth of the consequences resulting from the challenges in primary production. The vulnerability appeared as rough structural change that pushed the periphery into demographic isolation: "This rough structural change - no compensatory jobs were created. Forestry was a big loser, agriculture another" (I5). Small-scale farming became inadequate as a livelihood for the families who used to be dependent on hundreds of seasonal jobs in forest work:

People could not live there anymore. There was no livelihood for those families, big families, in those relatively small farms. Here forestry had constituted the major part, thousands of workers, and now we are speaking of tens or hundreds of forestry workers... [From the late] 1960s, about 600 people [per year] migrated in the top years (I6).

This description exemplifies the weak capacity of a system to adapt its economic structure in order to maintain the possibility of securing a livelihood.

The immediate response to this shock was described as the powerless reaction of giving up which poorly reflects the adaptation typical of growth regions. In the most eloquent proposal of the time, temporary bunkhouses were considered adequate for people passing through, highlighting how no means of resisting out-migration existed:

I remember when I was listening to the council session. The chairman of the council suggested ... that no development plans are needed. A bunkhouse behind the station, where people can stay temporarily. For those who have sold their land, forest and possessions, and are waiting for their money to get away (I1).

Adaptation appeared as a form of acceptance that the population was shrinking, whilst no capacity existed to create a survival strategy for the unemployed to adapt to this new situation on-site. The narratives imply that neither the rapid boom nor the bust were locally planned or manageable. 


\section{From recovering with the state to the darkening skyline}

The solutions from the early-1970s seem to be more balanced in socio-economic terms reflecting adaptation as recovery through both path dependency and re-orientation. Nevertheless, now that the forest industry had gone through rationalisation, the forest mills and other forest-related factories were seen as providing the foundation for industrial activities: "Lieksa has had strong industrial production, a sawmill and the Pankakoski Board Mill. It has been a strong industrial town after all" (I8). Here the narrative is interpreted as a reflection of path dependency in industrial development but also as an informal institutional convention that stresses the role of forest industries as the backbone of the town. The support of governmental industrial development support funding was considered crucial for re-orientation through job creation in light industries: “Quite a lot has been invested here in labour policy. Particularly the state has played a role in getting employment here. To establish industrial manufacturing and for that reason the industrial estate was established with the assistance of the state" (I1).

The case exemplifies the central role of the state and its formal institutional policy instruments in remapping a new role for the periphery. By controlling and steering the financial resources, the state was able to increase capacities that reduced the vulnerability and facilitated local adaptability, which turned the bust into recovery. The industrial estate established in the 1970 s was regarded as providing recovery as it smoothed out the losses in heavier industries and agriculture: "The industrial estate of Lieksa ... it has been a success story, when you consider how massively people left those rural areas" (I6). These greenfield investments did not constitute an expansion of existing industry; rather, the objective was to move from the processing of natural resources towards diversified manufacturing. This shift in industrial policy to promoting small- and medium-sized industry instead of just heavy industry represented a shift to renewal based on the growing demand for exported consumer goods boosted by the EFTA and Comecon agreements and the availability of labour.

The expansion of municipal health care and school reform in the early 1970 s played a key role in local development, also boosting local employment. The local episode, though, reflects a rather desperate attempt to use formal policies to resist the change but which hardly manifests the local capacity to sustain development in the long-term. The idea was based on the local model of scattered spatial structure: "There was talk about service villages, in the 1970s. ... [The service villages] had a bank and a post office, a couple of grocery stores, and a school" (I5). The model included the building of public rental houses in each village, but the interviewees merely saw this as a political misstep without any long-term rationality: "The Planning Secretary back then said: 'Oh my god! Why build there when there are no people?' ...Nevertheless, they were built, apparently it was political. ... Now there are [empty houses]. Impossible to sell" (I6).

In the 1980s, opportunities in the tourism industry were mooted now that the heyday of mass production was over and the declining competitiveness of manufacturing seemed obvious (Korhonen \& Tykkyläinen 1983). However, as both the recreational use of nature and environmental protection were raised as new developmental objectives, they provoked conflicts in forest use, especially at the turn of the 1990s (Eisto 2009). Locally, the disjuncture in interests was not experienced between the old and new industries but rather between different valuations of the economy and environment. Indeed, tourism and protection were in juxtaposition in Koli Hills:

The Metsähallitus [the state-owned forest administration] has been a relatively good master. With

it, we have managed. But we have had tough fights. ... This was because the Ministry of Environment tried to get these [areas] under its control and was not willing to develop these (I3).

This short episode represents the divergent formal policies of state government that remap differently the position of peripheries - this time hampering rather than assisting in reducing vulnerability and taking advantage of new economic possibilities as capacities for adaptation.

\section{Another bust shocking and out mapping the periphery}

The economic depression in the early-1990s was taken as a starting point that drastically changed the society and organisation of industries: "The recession in the 1990s changed Finland, made 
another kind of society, another kind of industry" (16). Further job losses in manufacturing were explained in the context of wider economic processes that transferred assembly and component manufacturing from Nordic peripheries to less expensive countries in Asia: "We still talk about the China Syndrome. ... Well, it is probably even cheaper in India nowadays. When salaries rise, production probably goes elsewhere" (16). This episode indicates the disruptions in protected trading networks following globalisation that did not so much change the role of the periphery in the global economic system but rather took it away. Other disruptions in the old type of nationally managed network fell upon agriculture, which confronted a bust the second time - this time after joining the European Union: "Structural change is visible in farming. ... Probably the EU affected for some part. I remember when Finland joined [the EU], in 1994 or a little earlier. ... Prices dropped, no possibilities to continue" (18). These narratives reflect the power of external changes in deepening the vulnerability and marginality of the periphery that was not in the hands of the locals or even the state anymore for that matter.

In Finland, new formal institutional policies in the 1990s concentrated very much on the development of hi-tech industries which influenced growth mainly in urban areas and practically bypassed the resource peripheries of this kind (Tykkyläinen et al. 2017). Locally this was also seen as a missed opportunity; they were overlooked because local policy-makers were stuck with conventional industries and the wider societal transformation was poorly recognised: "Lieksa could have invested in electronic businesses of this kind earlier ... efforts should have been made already in the 1980s. The development could have been different, but it is easy to say this in hindsight. ... Not only the traditional ones, agriculture and forestry" (12). Thus, the narrative reflects the informal institutional behaviour that prioritises conventional production, thus hindering the search for new opportunities and resources for industrial renewal.

\section{Expectations towards restructuring in a time of limited institutional power and uncertainty}

In the narratives, every kind of profitable industrial activity was considered an appropriate economic basis for the future, but the forest industries were still referred to as the backbone of local economic life: "Among others plenty of investments have still taken place in Kevätniemi Sawmill, and Pankakoski Board Mill is still working. They are the grounding pillars among the industries" (I3). A few examples that had managed to survive from the latest bust comprised a small collection of both natural-based and non-natural resource-based manufacturing: "Pankakoski [Board Mill] is one of the bigger employees, Joptek [manufacturing of rubber and plastic products], Kevätniemi Sawmill ...Some other entrepreneurs who have added to their workforces and expanded, Perhekokki which produces ready meals" (I3). Abandoning bulk production and concentrating on specialisation was considered most critical to ensuring these peripheral firms' competitiveness: "Here there has been relatively diverse and small-scale manufacturing, and merchandise is needed, not mass production" (16) and "Special know-how on a relatively large scale exists here" (I2). The restructuring was portrayed through the capacities of firms to renew their production thus reflecting the resilience of firms rather than putting any weight on formal institutional policies.

The institutional change towards neoliberal policies can be seen resulting from the policies of central government, as the state had the power to change the structures of the national economic networks. As the local decision-making was influenced by the changes in its environment, these new policies changed the local institutional behaviour:

Every now and then there is a discussion about support through the industrial estate... when these economic development programmes are under planning. One would think that the input of the municipality would be higher. But no, it does not fit with contemporary thinking. The EU-regulations and others work against it, so this kind of competitive advantage cannot be given (I5).

Apart from the formal institutional changes, the contradiction in informal institutional behaviour was increasing with the changing attitudes towards biased and sticky perception relating to the robustness of heavy industry: "These changes. For some, this is so difficult. They longed for those few big factories. ... The change has already happened in Lieksa. We are not dependent on one industry anymore" (I6). The experiences from the last bust also added the fear of industrial plants leaving which shifted 
expectations towards smaller industrial units: "I do not believe in these massive factories. On the contrary, they run away. ... Some kind of smaller industry is surely better" (I7).

Expectations were increasingly focusing on tourism although this seemed more like a vision than a concrete action: "It is under development. It is a dream for the future in Lieksa, that tourism could be increased" (I3). Expectations for its larger-scale development were focused on the Koli Hill Area with its national park which was seen as requiring interest in both the protection of the natural landscape and recreational tourism: "An understanding about protection, an understanding about this is also beneficial. Sources of conflict create a loss for everyone" (I6). Tourism in Ruunaa Rapids in the border backwoods was already identified as benefiting from forestry, as it had improved its accessibility by maintaining the public roads and the dense network of forest roads: "Some 10,000 tourists each year in the summer seasons and some thousands in the winter seasons. ... It stems from good road connections .... to Ruunaa and onwards via relatively good forest roads to stateowned land" (I1). These mindsets were quite different to those of the late-1980s debate, which was marked by conflicts.

Bio-energy has become very topical in Lieksa since the interviews, but the narratives produced only one brief mention about it - in addition in terms of the fact that expectations for employment are exaggerated: "This bio-energy, the climate issues. Plenty believe in these. But they're not able to employ as many as they say" (17). This perspective is quite different from the formal institutional policies of the town in 2018, only ten years after the interviews, as the town has planned to invest in infrastructure that supports the construction of a bio-refinery (Lieksa 2018a). It may be seen as a formal institutional turning point that facilitates the renewal of the industrial path by bridging local natural resources and manufacturing. This relatively rapid change represents the flexibility of local policy-makers to adapt to changes when the window of opportunity opens. By receiving support from the state and the EU through ERDF (European Regional Development Fund) funding granted by the Regional Council of North Karelia (Lieksa 2018b), Lieksa seems to be remapped as a resource periphery within a wider support system with a topical development theme again.

\section{Reflections regarding decision-making and relative adaptation with disharmonious framing}

When assessing resilience from the perspective of actors in local decision-making, the focus settles on their adaptability and the ability to develop capacities to tolerate their vulnerability, the uncertainties of their economic future and the difficulties of locals to influence it. The resilience of local decisionmaking demands the ability to endure their position in a periphery that appears to be far beyond the main centres: "Everybody else thinks about Lieksa as remote. ... They wonder how we live here, when there is nothing here" (12). This seems to result from the mental peripheralisation of actors at the national scale, which positions the town as too distant to benefit from economic action and hence reproduces a vision of the static downturn with no reflections on dynamicity in the future.

Nevertheless this periphery was supported by regional policy and EU projects, supra-regional actors were typically presented as obstructive parties who peripheralise the town without trying to support its capacity to be renewed:

As a Member of Parliament... we see the wide-ranging know-how that exists in different municipalities. But not everyone wants to know. ... Another Member of the Parliament [from the electoral district of the capital city] spoke right before me and said: 'What is the point of feeding any more money there, to those kinds of regions, draining regions?' (I7).

This example represents two informal institutional perceptions on two spatial scales that set the peripheries in a different structure - the first placing the emphasis on the renewal and the latter on the static downturn.

Local policy-makers were confronting the pressure on them to take responsibility for the planning of economic development for the future. However, the speed of the economic changes and the obscure direction of the state planning seem to be hampering the planning. In a sense, comprehensive formal institutional planning was dropped but informal conventions in policy-making still reflected the need for direction from the central level: 
The predictability of the world economy has got weaker and plans should be made faster. Longterm planning is done based on quarterly reports. Planning should be done but comprehensive planning is absent even at the level of the whole of Finland. We just have to adapt to this situation but how do we reckon with it? What should we do? (16).

When the obstacles to planning are overcome, local decision-making collides with the outdated structures of practical tools thus leaving them ill equipped to fulfil the objectives: "We have good municipal economic developmental programmes ... and there are good objectives. But as for the means - the municipality does not have them. It is mostly about creating an image and some infrastructure" (I5).

In spite of all the obstacles and downturns, local policy-makers have managed to hold on to their optimism for development and twist the understanding of "a good state" or "successful". At the time of the interviews, the financial crisis had been underway for two years, but had not hit the town severely. Indeed, the atmosphere was quite the opposite and this optimistic attitude was explained in an unusual way. Given that the town had been at the bottom for such a long time, small setbacks in the graph had become meaningless: "We have been in quite a good state, during this current recession, as we have lived quite steadily after the previous recession, at the bottom. Unemployment is very high. The impact of this banking crisis has hardly had any influence on Lieksa" (I2). It is important to understand that these statements are highly relative to the background of the severe busts.

No subsequent crisis has exceeded the bust in the late-1960s. From this point of view, the policymakers experienced and perceived Lieksa as a relatively successful industrial town since the early1970s. Adaptation on the periphery seems to require making good use of overcoming the most severe bust and formulating it as the capacity to tolerate vulnerability and to bounce forward in spite of repeated busts and restructuring phases:

We can talk about the survival story of Lieksa though. When we consider the factors that caused these migration flows. ... It must be remembered that living on those farms would have been impossible: 4-5 hectares under cultivation, 10-15 hectares of forest, 5-6 children, and no extraearnings for the men in forestry, as the work was done by machines. Still, it has been possible to construct this kind of industrial community, as it is now (I6).

From this perspective, the town has passed the phase where there was nothing for the future: "The former town manager used the phrase 'The last one turns out the light'. He represented a view that if we continue along this road, there will be a time when the town will no longer exist" (I1).

\section{Conclusions}

The paper's general objective was to question the point of view whereby peripheries are seen only through a static downturn with no reflections on dynamicity or adaption. As a starting point, the predestined position of peripheries was compromised, which required the remapping of the changing role of the periphery (Kortelainen \& Rannikko 2015; Kühn 2015). Dynamicity was explored by outlining the waves of restructuring and changes in adaptation which were here seen as the reflections of economic evolution and evolutionary resilience of peripheries (cf. Carlsson et al. 2014; Kotilainen et al. 2015; Hayter \& Nieweler 2018). Notwithstanding, the case study of Lieksa represents a typical downward periphery which has confronted an initial boom followed by a major bust (e.g. Clapp 1998), it also shows that development did not stop at the first bust. Firstly, this long-term examination supports the idea of regional waves (Ryser et al. 2014) of restructuring including simultaneous booms and busts depending on the industrial sector and the selected viewpoint. Secondly, it reveals two waves of restructuring which both include a type of regional bust followed by different kinds of recovery.

Common for both the busts investigated were the external changes in technologies and markets that pushed the local development into bust. The most explicit difference was shown in the recovery phases that manifest the changes in the structural environment that were governed by the formal national institutions. While the first recovery was assisted more by the formal policies, the second bust was deepened by the failure of support at the formal national level. Thus, the results reflect the role of institutional changes in the economic evolution and unevenness of places (cf. Hodgson 2009; 
MacKinnon et al. 2009; Hassink et al. 2014; Martin \& Sunley 2015a). The recovery of the second wave buttress the previous findings on peripheries after the institutional changes following the neoliberal policies (e.g. Markey \& Heisler 2010; Halseth 2017) and emphasises their vulnerability when a disturbance occurs. True to form based on previous studies (e.g. Halseth \& Ryser 2017; Hayter \& Nieweler 2018), either in this case there were no signs of improved structures to confront these disturbances although the expectations towards local policy-makers in this respect have not diminished, rather the opposite. This seems to have led to a situation where support and direction through the formal national institutions have been withdrawn while local government requires supportive changes in formal institutions in order to fulfil the expectations of developmental planning on one hand. On the other hand, local decision-making seems to be stuck to the informal convention as a follower of bigger national level planning. The changes in the local planning environment could be described as greater responsibility and expectations in increasingly obscure and fuzzy structures.

The critical voices towards quantified macro-level approaches were taken seriously by placing greater emphasis on human perspectives (Bristow \& Healy 2014; Gong \& Hassink 2017), which resulted in rather different perceptions in resilience (cf. Dawley et al. 2010). While the typical quantified examinations highlight success in adaptation as the measured outcomes showing recovery though growth, this human perspective offered an insight from the experiences of actors during the process of socio-economic adaptation and how it stagnates or bounces forward. Most importantly, these inductive narratives revealed the behaviours, interpretation, beliefs and expectations of actors before, during and after the phases of recovery, which fits poorly with the forms of adaptation that are shown through the numeric indicators. In general, the adaptation appears as powerless reactions when confronting and adapting to external changes. Reactions though are not presented in the same way from the beginning to the end, revealing the diversity of reactions from phase to phase. Adaptation is shown through the variation of giving up, forward-looking acceptance, desperate resistance, reorientation with external support and reconfiguring renewal with an optimistic attitude.

As such, adaptation does not necessarily result in resilience as success, but as a strategy for negotiating periods of turbulence; it may encompass an acceptance of the loss of some inhabitants or businesses, as long as the town retains its core industrial performances and ability to function. After a major bust and severe downturn, every kind of industrial activity has been considered an appropriate economic basis for the future, which seems to be requiring the reconciliation of different kinds of economic, recreational and environmental values. Forest industries were still referred to as the backbone that has created positive path dependency for industrial activity, but the experiences from both busts have added the fear of industrial plants leaving and increased expectations towards a more diversified economy.

In spite of all the obstacles and downturns, the local policy-makers have managed to twist the understanding of "a good state" or "successful", which seems to be a prerequisite for holding onto an optimistic and forward-looking orientation. Being at the bottom for such a long time and finding relative success from its history, small setbacks had become rather meaningless. The line between giving up, acceptance and resistance is thin, and all of these forms of adaptation may be seen as strategic steps taken in order to bounce forward - or drift into hindering path dependence, stagnation or decline with no future prospects. The resilience regarding the perspective of local governmental actors on the periphery seems to be emphasising their flexible adaptability and the ability to develop institutional capacities to tolerate their vulnerability, the uncertainties of their economic future and the difficulties of locals to influence it - and if anything - to act and bounce forward in spite of repetitive busts and restructuring phases.

\section{Notes}

${ }^{1}$ Value added (gross) is the value generated by any unit engaged in a production activity. In market production, it is calculated by deducting from the unit's output the intermediates (goods and services) used in the production process and in non-market production by adding up the compensation of employees, consumption of fixed capital and possible taxes on production and imports (Statistics Finland 2010). 
${ }^{2}$ Employment \% is the proportion of employed people in relation to the labour force (employed and unemployed in total) (Statistics Finland 2018a).

3 The so-called Swedish clearing (ns. ruotsalaisraivaus) meaning compensation for clearing land by the Swedish-speaking population: the Finnish-speaking population was settled in a way that would not alter the share of the Finnish- and Swedish-speaking populations in the municipalities of Finland. This released some of the Swedish-speaking land owners from their obligation to dispose of their land, but in such cases they were required to provide compensation by covering the costs for clearing fields elsewhere (Laitinen 1995; Land Acquisition Act 396/1945, 53§, 92 §).

\section{Acknowledgements}

I would like to thank the Kyösti Haataja Foundation for funding this research and the reviewers for their constructive comments.

\section{References}

Aarnio, J. (1999) Kaskiviljelystä metsätöihin: Tutkimus Pielisjärven kruununmetsistä ja kruununmetsätorppareista vuoteen 1910. Department of Geography, publications 4. University of Joensuu, Joensuu.

Adger, N. W. (2006) Vulnerability. Global Environmental Change 16(3) 268-281. https://doi.org/10.1016/j. gloenvcha.2006.02.006

Andrews, M. (2015) 'A very elementary transformation of one's existence': narrating moments of political change. In Reid, H. \& West, L. (eds.) Constructing Narratives of Continuity and Change: A Transdisciplinary Approach to Researching Lives, 37-48. Routledge, London and New York.

Bathelt, H. \& Glückler, J. (2014) Institutional change in economic geography. Progress in Human Geography 38(3) 340-363. https://doi.org/10.1177/0309132513507823

Boschma, R. (2015) Towards an evolutionary perspective on regional resilience. Regional Studies 49(5) 733-751. https://doi.org/10.1080/00343404.2014.959481

Boschma, R. \& Martin, R. (2007) Editorial: Constructing an evolutionary economic geography.Journal of Economic Geography 7 537-548. https://doi.org/10.1093/jeg/lbm021

Bristow, G. \& Healy, A. (2014) Regional resilience: an agency perspective. Regional Studies 48(5) 923935. https://doi.org/10.1080/00343404.2013.854879

Brown, K. (2016) Resilience, Development and Global Change. Routledge, London and New York.

Bryant, C. \& Joseph, A. E. (2001) Canada's rural population: trends in space and implications in place. The Canadian Geographer 45(1) 132-137. https://doi.org/10.1111/j.1541-0064.2001.tb01177.x

Carlsson, E., Steen, M., Sand, R. \& Nilsen, S. K. (2014) Resilient peripheral regions? The long-term effects of ten Norwegian restructuring programmes. Norsk Geografisk Tidsskrift - Norwegian Journal of Geography 68(2) 91-101. https://doi.org/10.1080/00291951.2014.894565

Central Statistical Office (1970) Statistical Yearbook of Finland: New series - 65th - Year 1969. IV Maanmittaus ja asustustoiminta, e. Clearing of Fields. Valtion painatuskeskus, Helsinki.

Clandinin, D. J. \& Connelly, F. M. (2000) Narrative Inquiry: Experience and Story in Qualitative Research. Jossey-Bass Publisher, San Francisco.

Clapp, R. A. (1998) The resource cycle in forestry and fishing. Canadian Geographer/Le Géographe Canadien 42(2) 129-144. https://doi.org/10.1111/j.1541-0064.1998.tb01560.x

Dawley, S. Pike, A. \& Tomaney, J. (2010) Towards the resilient region? Local Economy 25(8) 650-667. https://doi.org/10.1080/02690942.2010.533424

Deacon, L. \& Lamanes, T. (2015) Resiliency and resource-based communities: a Canadian case study. Sustainable Development and Planning VII 193 719-724. https://doi.org/10.2495/SDP150601

Eisto, I.(2009) Kylläpä kestää:Paikallisestikestävän kehityksenjaympäristölähtöisen kehittämistoiminnan suhde harvaanasutulla maaseudulla [Still on the path? Assessing the relationship between environment-based rural development interventions and local sustainability]. Dissertations in Social Sciences. Joensuun yliopiston yhteiskuntatieteellisiä julkaisuja nro 1. (in Finnish) http:// epublications.uef.fi/pub/urn_isbn_978-952-219-299-8/urn_isbn_978-952-219-299-8.pdf

Essletzbichler, J. \& Rigby, D. (2007) Exploring evolutionary economic geographies. Journal of Economic Geography 7 549-571. https://doi.org/10.1093/jeg/lbm022 
Estola, E., Uitto, M. \& Syrjälä, L. (2017) Elämäkertahaastattelu. In Hyvärinen, M., Nikander, P. \& Ruusuvuori, J. (eds.) Tutkimushaastattelun käsikirja, 153-173. Vastapaino, Tampere.

Freudenburg, W. R. (1992) Addictive economies: extractive industries and vulnerable localities in a changing world economy. Rural Sociology 57(3) 305-332. https://doi.org/10.1111/j.1549-0831.1992. tb00467.x

Gong, H., \& Hassink, R. (2017) Regional resilience: the critique revisited. In Williams, N. \& Vorley, T. (eds.) Creating Resilient Economies: Entrepreneurship, Growth and Development in Uncertain Times, 206-216. Edward Elgar, Cheltenham and Northampton. https://doi. org/10.4337/9781785367649.00021

Halonen, M., Kotilainen, J., Tykkyläinen, M. \& Vatanen, E. (2015) Industry life cycles of a resource town in Finland - the case of Lieksa. European Countryside 7(1) 16-41. https://doi.org/10.1515/ euco-2015-0002

Halseth, G. (2017) Introduction: political economy perspectives on the transformation of resource towns and peripheries. In Halseth, G. (ed.) Transformation of Resource Towns and Peripheries: Political Economy Perspectives, 1-10. Routledge, Abingdon, Oxon and New York.

Halseth, G. \& Ryser, L. (2017) Towards a Political Economy of Resource-Dependent Regions. Routledge, Abingdon, Oxon and New York. https://doi.org/10.4324/9781315225296

Halseth, G., Ryser, L. \& Markey, S. (2017) Localization and globalization: industrial Reorganization in MacKenzie, British Columbia. In Halseth, G. (ed.) Transformation of Resource Towns and Peripheries: Political Economy Perspectives, 51-84. Routledge, Abingdon, Oxon and New York.

Hassink, R. (2010) Regional resilience: a promising concept to explain differences in regional economic adaptability? Cambridge Journal of Regions, Economy and Society 3 45-58. https://doi. org/10.1093/cjres/rsp033

Hassink, R., Klaerding, C. \& Marques, P. (2014) Advancing evolutionary economic geography by engaged pluralism. Regional Studies 48(7) 1295-1307. https://doi.org/10.1080/00343404.2014.889815

Hayter, R. (2000) Flexible Crossroads: The Restructuring of British Columbia's Forest Economy. UBC Press, Vancouver and Toronto.

Hayter, R. \& Nieweler, S. (2018) The local planning-economic development nexus in transitioning resource-industry towns: reflections (mainly) from British Columbia. Journal of Rural Studies 60 82-92. https://doi.org/10.1016/j.jrurstud.2018.03.006

Hayter, R., Barnes, T. J. \& Bradshaw, M. J. (2003) Relocating resource peripheries to the core of economic geography's theorizing: rationale and agenda. Area 35(1) 15-23. https://doi. org/10.1111/1475-4762.00106

Helminen, V., Nurmio, K., Rehunen, A., Ristimäki, M., Oinonen, K., Tiitu, M., Kotavaara, O., Antikainen, H., \& Rusanen, J. (2014) Kaupunki-maaseutu-alueluokitus: Paikkatietoihin perustuvan alueluokituksen muodostamisperiaatteet. Suomen ympäristökeskuksen raportteja 14/2014.

Henning, M., Stam, E. \& Wenting, R. (2013) Path dependence research in regional economic development: cacophony or knowledge accumulation? Regional Studies 47(8) 1348-1362. https:// doi.org/10.1080/00343404.2012.750422

Hodgson, G. M. (2009) Agency, institutions, and Darwinism in evolutionary economic geography. Economic Geography 85(2) 167-173. https://doi.org/10.1111/j.1944-8287.2009.01020.x

Hudson, R. (2005) Rethinking change in old industrial regions: reflecting on the experiences of North East England. Environment and Planning 37 581-596. https://doi.org/10.1068/a36274

Hudson, R. (2009) Resilient regions in an uncertain world: wishful thinking or a practical reality? Cambridge Journal of Regions, Economy and Society 3(1) 11-25. https://doi.org/10.1093/cjres/rsp026

Hyvärinen, M. (2017) Kertomushaastattelu. In Hyvärinen, M., Nikander, P. \& Ruusuvuori, J. (eds.) Tutkimushaastattelun käsikirja, 174-192. Vastapaino, Tampere.

Isaksen, A. (2015) Industrial development in thin regions: trapped in path extension? Journal of Economic Geography 15(3) 585-600. https://doi.org/10.1093/jeg/lbu026

Jacquet, J. B. \& Kay, D. L. (2014) The unconventional boomtown: updating the impact model to fit new spatial and temporal scales. Journal of Rural and Community Development 9(1) 1-23.

Keough, S. B. (2015) Planning for growth in a natural resource boomtown: challenges for urban planners in Fort McMurray, Alberta. Urban Geography 36(8) 1169-1196. https://doi.org/10.1080/0 2723638.2015.1049482

Kiander, J. (2001) Laman opetukset: Suomen 1990-Iuvun kriisin syyt ja seuraukset. Government Institute for Economic Research, Discussion Papers No. 27(5). Government Institute for Economic Research, Helsinki. 
Korhonen, M. \& Tykkyläinen, M. (1983) Lieksan luonnonvaroista ja niiden hyödyntämismahdollisuuksista. Lieksan kaupunki, Luonnonvarojen hyödyntämisprojektin julkaisuja no 1.

Kortelainen, J. (2010) Aluepolitiikka. In Niemelä, P. (ed.) Hyvinvointipolitiikka, 346-366. WSOYpro Oy, Helsinki.

Kortelainen, J. \& Rannikko, P. (2015) Positionality switch: remapping resource communities in Russian borderlands. Economic Geography 91(1) 59-82. https://doi.org/10.1111/ecge.12064

Kotilainen, J., Eisto, I., \& Vatanen, E. (2015) Uncovering mechanisms for resilience: Ssrategies to counter shrinkage in a peripheral city in Finland. European Planning Studies 23(1) 53-68. https:// doi.org/10.1080/09654313.2013.820086

Kotilainen, J. Halonen, M., Vatanen, E. \& Tykkyläinen, M. (2017) Finland: resource town transitions in Finland: local impacts and policy responses in Lieksa. In Halseth, G. (ed.) Transformation of Resource Towns and Peripheries: Political Economy Perspectives, 296-316. Routledge, Abingdon, Oxon and New York.

Krippendorff, K. (2004) Content Analysis: An Introduction to its Methodology. $2^{\text {nd }}$ ed. SAGE Publications, Thousands Oaks, London and New Delhi.

Kühn, M. (2015) Peripheralization: theoretical concepts explaining socio-spatial inequalities. European Planning Studies 23(2) 367-378. https://doi.org/10.1080/09654313.2013.862518

Laitinen, E. (1995) Vuoden 1945 maanhankintalain synty, sisältö ja toteutus. In Laitinen, E. (ed.) Rintamalta raiviolle: Sodanjälkeinen asutustoiminta 50 vuotta, 52-138. Atena kustannus, Jyväskylä.

Land Acquisition Act 369/1945.

Lehtonen, O. \& Tykkyläinen, M. (2014) Potential job creation and resource dependance in rural Finland. European Countryside 6(3) 202-224. https://doi.org/10.2478/euco-2014-0011

Lieksa (1980) Municipal report of Lieksa 1979.

Lieksa (2018a) Lieksan kaupungin talousarvio vuodelle 2018. 445/10.100/2017.

Lieksa (2018b) Lieksan kaupungin Kevätniemen bioterminaarialueen rakentamisen kilpailutus käynnissä. Lieksan uutisarkisto. <http://www.lieksa.fi/uutiset/-/asset publisher/AqOEBCRUCqCz/ content>. 29.5.2018.

Maatalousministeriön asutusasiainosasto (1953) Statistical data: results of settlement activity under the Land Acquisition Act and supplementary legislation. 10. Clearing of field under the Acquisition Act. Asutustoiminnan Aikakauskirja 3/1953.

MacKinnon, D., Cumbers, A., Pike, A. Birch, K. \& McMaster, R. (2009) Evolution in economic geography: institutions, political economy, and adaptation. Economic Geography 85(2) 129-150. https://doi. org/10.1111/j.1944-8287.2009.01017.x

Markey, S. \& Heisler, K. (2010) Getting a fair share: regional development in a rapid boom-bust rural setting. Canadian Journal of Regional Science 33(3) 49-62.

Markey, S., Halseth, G. \& Manson, D. (2012) Investing in Place: Economic Renewal in Northern British Columbia. UBC Press, Vancouver and Toronto.

Martin, R. (2000) Institutional approaches in economic geography. In Sheppard, E. \& Barnes, T. J. (eds.) A Companion to Economic Geography, 77-94. Blackwell Publishers Ltd., Oxford and Massachusetts.

Martin, R. (2012) Regional economic resilience, hysteresis and recessionary shocks. Journal of Economic Geography 12 1-32. https://doi.org/10.1093/jeg/lbr019

Martin, R. \& Sunley, P. (2006) Path dependence and regional economic evolution. Journal of Economic Geography 6 395-437. https://doi.org/10.1093/jeg//bl012

Martin, R. \& Sunley, P. (2015a) Towards a developmental turn in evolutionary economic geography? Regional Studies 49(5) 712-732. https://doi.org/10.1080/00343404.2014.899431

Martin, R. \& Sunley, P. (2015b) On the notion of regional economic resilience: conceptualization and explanation. Journal of Economic Geography 15 1-42. https://doi.org/10.1093/jeg/lbu015

Moisio, S. \& Leppänen, L. (2007) Towards a Nordic competition state? Politico-economic transformation of statehood in Finland 1965-2005. Fennia 185(2) 63-87.

Pendall, R., Foster, K. A. \& Cowell, M. (2010) Resilience and regions: building understanding of the metaphor. Cambridge Journal of Regions, Economy and Society 3(1) 71-84. https://doi.org/10.1093/ cjres/rsp028

Pike, A., Birch, K., Cumbers, A., MacKinnon, D. \& McMaster, R. (2009) A geographical political economy of evolution in economic geography. Economic Geography 85(2) 175-182. https://doi.org/10.1111/ j.1944-8287.2009.01021.x

Pike, A. Dawley, S. \& Tomaney, J. (2010) Resilience, adaptation and adaptability. Cambridge Journal of Regions, Economy and Society 3(1) 1-12. https://doi.org/10.1093/cjres/rsq001 
Pike, A., MacKinnon, D., Cumbers, A., Dawley, S. \& McMaster, R. (2016) Doing evolution in economic geography. Economic Geography 92(2) 123-144. https://doi.org/10.1080/00130095.2015.1108830

Pinnegar, S. \& Daynes, J. G. (2007) Locating narrative inquiry historically: thematics in the turn to narrative. In Clandinin, D. J. (ed.) Handbook of Narrative Inquiry: Mapping a Methodology, 3-34. SAGE Publications, Thousands Oaks, London and New Delhi. https://doi. org/10.4135/9781452226552.n1

Polèse, M. \& Shearmur, R. (2006) Why some regions will decline: a Canadian case study with thoughts on local development strategies. Papers in Regional Science 85(1) 23-46. https://doi. org/10.1111/j.1435-5957.2006.00024.x

Rannikko, P. (1999) Savottojen ja väestökadon Suomi. In Löytönen, M. \& Kolbe, L. (eds.) Suomi: Maa, kansa ja kulttuuri, 211-221. Suomen Kirjallisuuden Seuran Toimituksia 753, Jyväskylä.

Ryser, L., Markey, S.,Manson, D., \& Halseth, G. (2014) From boom and bust to regional waves: development patterns in the Peace River region, British Columbia. Journal of Rural and Community Development 9(1) 87-111.

Ryser, L., Halseth, G., Markey, S., Gunton, C. \& Argent, N. (2018) Path dependency or investing in place: understanding the changing conditions for rural resource regions. The Extractive Industries and Society 6(1) 29-40. https://doi.org/10.1016/j.exis.2018.10.009

Saarelainen, A. (1995) Raivaussavuista euroaikaan. Pielisjärven maaseutu yhteiskunnan muutoksissa 1945-1995. In Laitinen, E. (ed.) Rintamalta raiviolle: Sodanjälkeinen asutustoiminta 50 vuotta, 184238. Atena kustannus, Jyväskylä.

Simmie, J. \& Martin, R. (2010) The economic resilience of regions: towards an evolutionary approach. Cambridge Journal of Regions, Economy and Society 3(1) 27-43. https://doi.org/10.1093/cjres/rsp029

Statistics Finland (1979) Väestön elinkeino: Väestö elinkeinon mukaan kunnittain 1880-1975. Tilastollisia tiedonantoja 63. Tilastokeskus, Helsinki.

Statistics Finland (1982) 201 -- Population over 15 years by sex and belonging to labour force 1980. Unpublished data printout 17.12.1982.

Statistics Finland (2010) 905 -- Tuotanto ja työllisyys seutukunnittain 1975-2008. <http://pxnet2.stat. fi/PXWeb/pxweb/fi/StatFin_Passiivi/StatFin_Passiivi_kan_altp/statfinpas_altp_pxt_905_200800e_fi. px/?rxid=bfbfa614-26ae-4f71-8daa-50aa1e36e081>. 17.12.2010.

Statistics Finland (2018a) 001 - Population by area, main type of activity, sex, age and year 19872017. <http://pxnet2.stat.fi/PXWeb/pxweb/en/StatFin/StatFin_vrm_tyokay/statfin_tyokay_pxt_001. px/?rxid $=e f a 5 c 872-c f 43-4 d 90-926 b-66655 a 221 f 42>17.12 .2018$.

Statistics Finland (2018b) 009 -- Employed labour force in area (workplaces) by area, employer sector, sex and year 1987-2016. <http://pxnet2.stat.fi/PXWeb/pxweb/en/StatFin/StatFin vrm tyokay/ statfin_tyokay_pxt_009.px/?rxid=efa5c872-cf43-4d90-926b-66655a221f42>. 21.9.2018.

Suorsa, K. (2007) Regionality, innovation policy and peripheral regions in Finland, Sweden and Norway. Fennia 185(1) 15-29.

Tykkyläinen, M. (1995) Asutustoiminnan taloudelliset vaikutukset. In Laitinen, E. (ed.) Rintamalta raiviolle: Sodanjälkeinen asutustoiminta 50 vuotta, 139-158. Atena kustannus, Jyväskylä.

Tykkyläinen, M. (2015) Turmoil in rural communities as an extreme event exemplified by the cases of Hungary and the Russian North. Geographische Zeitschrift 103(1) 37-55.

Tykkyläinen, M., Vatanen, E., Halonen, M. \& Kotilainen, J. (2017) Finland: global-local links and industrial restructuring in a resource town in Finland: the case of Lieksa. In Halseth, G. (ed.) Transformation of Resource Towns and Peripheries: Political Economy Perspectives, 85-111. Routledge, Abingdon, Oxon and New York.

Vatanen, E. \& Kotilainen, J. (2016) Paikallistalouksien uusiutumiskyky: itäsuomalaisia esimerkkejä. Terra 129(3) 176-186.

Yin, R. K. (2003) Case Study Research: Design and Methods. $3^{\text {rd }}$ ed. Applied Social Research Methods Series vol. 5. SAGE Publications, Thousand Oaks. 